\title{
THE HELLENIC SOCIETY
}

The Society for the Promotion of Hellenic Studies was founded in 1879 to advance the study of Greek language, literature, history and art. It maintains in London, jointly with the Roman Society and in association with the Institute of Classical Studies of the University of London, a library of some 40,000 volumes, and a large collection of lantern slides. Both books and slides can be sent to members by post. Meetings with lectures are held in London four times a year and in various parts of the country in collaboration with local associations. The Fournal of Hellenic Studies is recognised as one of the foremost British periodicals in the field of classical scholarship. It contains articles on a wide range of subjects, illustrations and book reviews.

The Fournal and the Archaeological Reports are sent free to members. The annual subscription to the Society is $£_{7}$. For information about the Society write to the Secretary, The Hellenic Society, 3I-34 Gordon Square, London, WCi H oPP.

\section{THE BRITISH SGHOOL AT ATHENS}

The British School at Athens was founded in I 886 to provide British students of the language, literature, history, religion, archaeology and art of Greece from prehistoric times to the present day with facilities for research and travel in Greek lands. The School premises in Athens house the Penrose Library and the Finlay Library, which together cover every aspect of Greek studies, ancient and modern. Accommodation is available in the School for postgraduate students and senior scholars during the Session, from October until the end of June. Other students and teachers of Classics, visiting Greece for shorter periods, may be accommodated during July and August. The School also maintains a Dig-house in Crete, at Knossos, which serves as a base for excavations and for students engaged in research.

The School also accepts holders of studentships and travelling fellowships from all Universities of the Commonwealth, and students of the other British Schools and Institutes abroad. A School Studentship is offered every year to a graduate in Classics or Archaeology from any university of the U.K. and Eire. Other Students are appointed on the Macmillan and Sachs endowments.

The School has sponsored or undertaken many excavations in Greek lands. The most important since the war have been conducted at Knossos, Mycenae, Old Smyrna, Lefkandi in Euboea, and on Chios. The results of these excavations are published in the Annual of the British School at Athens, or in its Supplementary volumes, and full preliminary reports on them appear in the Archaeological Reports.

For further information, write to the Secretary, The British School at Athens, $3 \mathbf{I}-34$ Gordon Square, London, $\mathrm{WC}_{\mathrm{I}} \mathrm{H}$ oPP.

\section{THE INSTITUTE OF GLASSICAL STUDIES PHOTOGRAPHIC ARGHIVE}

The Institute of Classical Studies wishes to draw attention to the existence of its photographic archive which includes classical antiquities (other than Romano-British) in private and public collections in this country. It is hoped to make the coverage of the archive as complete as possible and information from readers about objects of this kind would be extremely helpful. Photographs would be particularly valuable. The archive also includes photographs of a substantial proportion of the Greek Dramatic Monuments listed by Professor Webster in BICS Supplements $9(=23)$, I I $(=24)$ and I 4 $(=20)$ and photographs of $65^{\circ}$ papyri, mostly literary and mostly published in Oxyrhynchus Papyri and now dispersed. 